Revista de Cercetare si Interventie Sociala

ISSN: 1583-3410 (print), ISSN: 1584-5397 (electronic)

\title{
EVALUATION INDEX SYSTEM AND MEASUREMENT OF HIGH-QUALITY DEVELOPMENT IN CHINA
}

Xinhuan HUANG, Binqing CAI, Yalin LI

Revista de cercetare și intervenție socială, 2020, vol. 68, pp. 163-178

https://doi.org/10.33788/rcis.68.11

Published by:

Expert Projects Publishing House

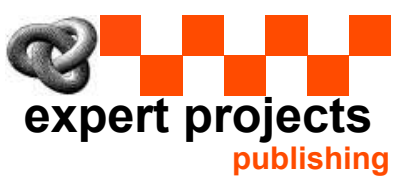

On behalf of:

„Alexandru Ioan Cuza” University,

Department of Sociology and Social Work

and

HoltIS Association

REVISTA DE CERCETARE SI INTERVENTIE SOCIALA is indexed by Clarivate Analytics (Social Sciences Citation Index), SCOPUS and CROSSREF 


\title{
Evaluation Index System and Measurement of High-quality Development in China
}

\author{
Xinhuan HUANG ${ }^{1}$, Binqing $\mathrm{CAI}^{2}$, Yalin $\mathrm{LI}^{3}$
}

\begin{abstract}
There are lack of indicator system and method to measure high-quality development. According to the new development concept and the system theory, we put forward that high-quality development system should be a system that not only realizes the development of subsystems at a high level but also achieves coordinated development among subsystems. Evaluation index system of China's high-quality development is established from the five aspects such as innovation development, urban-rural coordination, ecological environment, opening to the outside world and people's livelihood. The improved G1 method based on grey correlation degree and coordination degree model based on bull's-eye distance are applied to analyze high-quality development level of China's 30 provinces in 2016. The results show that the high-quality development among provinces is imbalanced, and presents the obviously spatial pattern of east high and west low. Parts of provinces are in the high development but low coordination state, or in low development but high coordination state. Opening to the outside world and ecological environment subsystem are the weak spot of high-quality development system. Opening to the outside world subsystem is with the most imbalanced development, followed by innovation development subsystem.
\end{abstract}

Keywords: high-quality development, comprehensive development degree, coordination degree.

\section{Introduction}

Since the reform and opening up, China's economy has maintained a high growth speed, and China has become the second largest economy in the world. Meanwhile, China's economic development has faced with inadequate and uncoordinated

1 Fujian Normal University, School of Economics, Fuzhou, CHINA.E-mail: xinhuanhsy@163.com

${ }^{2}$ Fujian University of Technology,School of Management, Fuzhou, CHINA. E-mail: binq1107@163.com (Corresponding author)

3 Fujian Normal University, School of Economics, Fuzhou, CHINA.E-mail: liyalin0211e@163.com 
problems, such as low economic efficiency, structural imbalance, environmental pollution, widening income gap, etc. (Chen \& Chen, 2018).Therefore, China's economy must shift from a stage of high-speed growth to a stage of high-quality development. High-quality development has become fundamental requirement and the latest direction of China's economic development.

High quality development of China's economic corresponds to high-speed growth in the past. High-speed growth is easier to grasp and account in statistics (Jin, 2018), and measuring high-speed growth has a wealth of theoretical research and practical application. High-quality development is with rich connotation, how to carry out the statistical accounting of high-quality development is a new and complex subject (Jin, 2018). It is necessary to establish a new value judgment of economic development, and develop a high-quality development evaluation system, include indicator system, standard system, statistical system (Ren \& Wen, 2018). Therefore, many scholars have carried out a heated discussion and interpretation on high-quality development, and mainly focus on connotation, characteristics and paths, etc. (Jin, 2018; Ren \& Li, 2018; Chen \& Chen ,2018). In conclusion, high-quality development should be the development embodying new development concepts. It is the development that innovation becomes the first power, coordination becomes the endogenous characteristic, green becomes the universal form, opening becomes the only way, sharing becomes the fundamental goal.

After that, some scholars focus on the relationship between innovation, coordination, green, opening, sharing and high-quality development. National innovation (Liu, Zhang \& Zhu, 2019), technological innovation (Li \& Zeng, 2019)are the driving force of economic high-quality development. Enhancing the construction of new countryside, narrowing the gap between urban and rural development (Xu, Zheng \& Zhang,2 019)and industrial structure change (Yang $\& \mathrm{Li}, 2019)$ are conducive to high-quality development. The governance of haze pollution (Chen \& Chen, 2018), the coordination of the industrialization and environmental quality (Yuan, Di \& Li, 2018; Li et al., 2019) are critical to achieve high-quality development. Not only the introduction and utilization of foreign direct investment but also the development of outward foreign direct investment can improve the quality of China's economic growth (Tian, Li \& Wang, 2019). The criterion of high-quality development is to enable people to enjoy the fruits of development (Huang \& Ren, 2019; Ruan \& Liu, 2019). Total factor productivity (Liu, Zhang \& Zhu, 2019; Li \& Zeng,2 019), real GDP per capita (Chen \& Chen, 2018; Yang \& Li, 2019), real labor wage and proportion of high-quality population (Tian, Li \& Wang, 2019) are used to measure high-quality development of China's economic.

Other scholars develop conceptual models and index systems for high-quality development from new development concept. Wang, Li \& Xu (2019) develop the index system for high-quality development driven by science and technology innovation, including two stages such as technological innovation and high- 
quality economic development. Huang \& Ren (2019) propose high-quality development index system based on people-centered development mode, including five dimensions such as income, health, education, sustainable development and improvement of people's livelihood. Ruan \& Liu (2019) define the theoretical connotation of development fruits under the sharing concept, and develop a corresponding index system of development fruits that includes four dimensions such as development speed, development structure, development quality, and development achievement. Wei \& Li (2018) propose a measurement system of economic high-quality development level from ten aspects such as optimization of economic structure, development driven by innovation, efficient resource allocation, perfection of market mechanism, stability of economic growth etc..

High-quality development is a systematic project with remarkable characteristics of system, multi-dimension and coordination (Jin, 2018; Ren \& Li, 2018; Ren \& Wen, 2018; An, 2018). High-quality development emphasizes the combination of economic benefits, social benefits and ecological benefits, and embodies an inclusive growth coordinating among human beings, economic and society. High-quality development is conducive to achieving adequate and coordinated development of China's economic. Adequate development refers to the development with sufficient innovation capability, high efficiency of resource utilization, the balanced development of social undertakings, the friendly ecological environment, and the perfect well-being of people's livelihood. Balanced development mainly manifests in the balance of regional and urban-rural development. Balanced regional development mainly means that regional development gap and income gap are relatively small. Balanced urban-rural development mainly refers to the small gap between urban and rural residents in the fields of income, employment, old-age care, medical care, education, and infrastructure and so on (Ren \& Li, 2018; Xu, Zheng \& Zhang, 2019).

According to the new development concept and the system theory, we put forward that China's high-quality development system is an organic whole composed of five subsystems such as innovation development, urban-rural coordination, ecological environment, opening to the outside world and people's livelihood. High-quality development system should be a system that not only realizes the development of five subsystems at a high level but also achieves coordinated development among five subsystems. We use comprehensive development degree, coordination degree, and coordinated development degree to measure high-quality development. Comprehensive development degree is a comprehensive measure of the development degree of five subsystems. Coordination degree describes the state of harmony and optimization among five subsystems. Coordinated development degree is the integration of comprehensive development degree and coordinated degree, which is used to describe the high-quality development level.

The remainder of this paper is structured as follows: high-quality development evaluation index system is established from five dimensions such as innovation development, urban-rural coordination, ecological environment, opening to the 
outside world, and people's livelihood in section 2. Evaluation methods including improved G1 method based on grey correlation degree, and the coordination degree model based on bull's-eye distance are briefly described in section 3.In section 4, these methods are jointly applied to measure high-quality development level for China's 30 provinces, municipalities and autonomous regions in 2016. The results are briefly concluded, and the policy proposals are put forward to promote China's high-quality development in section 5 .

\section{Evaluation Index System of High-quality Development}

The evaluation index system of high-quality development is constructed from five aspects such as innovation development, urban-rural coordination, ecological environment, opening to the outside world and people's livelihood. Based on the principles of science, integrity, universality and operability, China's high-quality development evaluation index system is established by drawing on the findings of some representative literature (Wang, 2017; Yang, Yang \& Li 2018; Wei \& Li, 2018; Shi \& Li, 2019), which is shown in Table 1.

Table 1: Evaluation index system of high-quality development

\begin{tabular}{|c|c|c|c|c|}
\hline Subsystem & System Element & Index & Weight & Unit \\
\hline \multirow{11}{*}{ 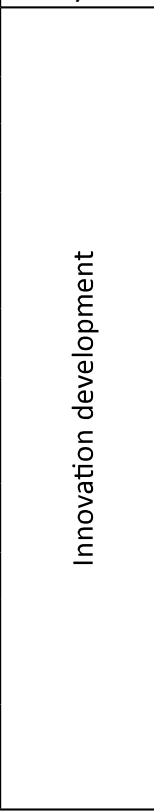 } & \multirow{2}{*}{ Macro efficiency } & Per Capita Gross Regional Product & 0.0949 & $\begin{array}{l}\text { Yuan/ } \\
\text { person }\end{array}$ \\
\hline & & Gross Regional Product Indices & 0.0591 & Null \\
\hline & \multirow{2}{*}{ Micro efficiency } & Overall Labor Productivity & 0.0836 & $\begin{array}{c}10000 \text { Yuan/ } \\
\text { person }\end{array}$ \\
\hline & & $\begin{array}{c}\text { Ratio of Profits to Total Industrial } \\
\text { Costs }\end{array}$ & 0.0803 & $\%$ \\
\hline & \multirow{4}{*}{$\begin{array}{l}\text { Structural } \\
\text { optimization }\end{array}$} & Industrialization Rate & 0.0643 & $\%$ \\
\hline & & $\begin{array}{l}\text { Proportion of Output Value of } \\
\text { Tertiary Industry in GDP }\end{array}$ & 0.0811 & $\%$ \\
\hline & & \begin{tabular}{|c|} 
Proportion of Employment in Tertiary \\
Industry to Total Employment \\
Population
\end{tabular} & 0.0764 & $\%$ \\
\hline & & $\begin{array}{c}\text { Proportion of High-tech Industry } \\
\text { Employees in Total Employment }\end{array}$ & 0.1154 & $\%$ \\
\hline & \multirow{3}{*}{$\begin{array}{l}\text { Innovation } \\
\text { input and output }\end{array}$} & R\&D Investment Intensity & 0.1203 & $\%$ \\
\hline & & $\begin{array}{c}\text { R\&D Personnel Full-time Equivalent } \\
\text { Scientific and Technological } \\
\text { Achievements }\end{array}$ & 0.1177 & $\begin{array}{c}\text { Item/ } \\
\text { person-year }\end{array}$ \\
\hline & & $\begin{array}{l}\text { Proportion of New Product Sales } \\
\text { Revenue in Total Sales Revenue of } \\
\text { Industrial Enterprises }\end{array}$ & 0.1070 & $\%$ \\
\hline
\end{tabular}




\begin{tabular}{|c|c|c|c|c|}
\hline \multirow{8}{*}{ 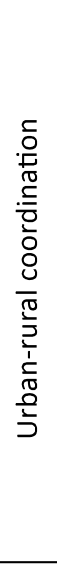 } & Urbanization & Urbanization Rate & 0.1259 & $\%$ \\
\hline & \multirow{2}{*}{$\begin{array}{c}\text { Income } \\
\text { consumption }\end{array}$} & $\begin{array}{l}\text { Ratio of Urban and Rural Residents' } \\
\text { Income }\end{array}$ & 0.1365 & $\%$ \\
\hline & & $\begin{array}{l}\text { Ratio of Urban and Rural Residents' } \\
\text { Consumption }\end{array}$ & 0.1341 & $\%$ \\
\hline & \multirow[b]{2}{*}{ Medical security } & $\begin{array}{l}\text { Ratio of Doctors Per 10,000 People } \\
\text { between Urban and Rural Areas }\end{array}$ & 0.1324 & $\%$ \\
\hline & & $\begin{array}{l}\text { Ratio of Beds Per } 10,000 \text { People } \\
\text { in Medical and Health Institutions } \\
\text { between Urban and Rural Areas }\end{array}$ & 0.1301 & $\%$ \\
\hline & \multirow{3}{*}{ Infrastructure } & $\begin{array}{c}\text { Ratio of Per Capita Road area } \\
\text { between Urban and Rural }\end{array}$ & 0.1134 & $\%$ \\
\hline & & $\begin{array}{c}\text { Ratio of Per Capita Park Green Area } \\
\text { between Urban and Rural }\end{array}$ & 0.1214 & $\%$ \\
\hline & & $\begin{array}{c}\text { Ratio of Water Use Penetration Rate } \\
\text { between Urban and Rural }\end{array}$ & 0.1063 & $\%$ \\
\hline \multirow{10}{*}{ 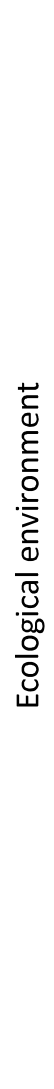 } & \multirow[t]{2}{*}{$\begin{array}{l}\text { Energy } \\
\text { efficiency }\end{array}$} & $\begin{array}{c}\text { Energy Consumption Per 10,000 } \\
\text { Yuan } \\
\text { of GDP }\end{array}$ & 0.0949 & $\begin{array}{l}\text { Tons of } \\
\text { standard } \\
\text { coal }\end{array}$ \\
\hline & & $\begin{array}{l}\text { Water Consumption Per } 10,000 \\
\text { Yuan of GDP }\end{array}$ & 0.1208 & $\begin{array}{l}\text { Cubic } \\
\text { metre }\end{array}$ \\
\hline & \multirow{2}{*}{$\begin{array}{l}\text { Pollution } \\
\text { abatement }\end{array}$} & $\begin{array}{c}\text { Wastewater Discharge Amount } \\
\text { Per } 10,000 \text { Yuan of GDP }\end{array}$ & 0.0787 & Ton \\
\hline & & $\begin{array}{c}\text { Emission of Sulfur Dioxide in } \\
\text { Exhaust Gas Per 10,000 Yuan of } \\
\text { GDP }\end{array}$ & 0.1288 & Ton \\
\hline & \multirow{3}{*}{$\begin{array}{l}\text { Environmental } \\
\text { Management }\end{array}$} & $\begin{array}{c}\text { Comprehensive Utilization Rate } \\
\text { of Industrial Solid Waste }\end{array}$ & 0.0770 & $\%$ \\
\hline & & $\begin{array}{c}\text { Harmless Disposal Rate of } \\
\text { Domestic Garbage }\end{array}$ & 0.0586 & $\%$ \\
\hline & & $\begin{array}{c}\text { Ratio of Industrial Pollution } \\
\text { Control Investment to Industrial } \\
\text { Added Value }\end{array}$ & 0.1221 & $\%$ \\
\hline & \multirow{3}{*}{ Natural Ecology } & $\begin{array}{c}\text { Area of Nature Reserves } \\
\text { as Percentage of Area of } \\
\text { Jurisdiction }\end{array}$ & 0.1076 & $\%$ \\
\hline & & Forest Coverage Rate & 0.0895 & $\%$ \\
\hline & & $\begin{array}{l}\text { Proportion of Direct Economic } \\
\text { Loss of Natural Disasters in GDP }\end{array}$ & 0.1219 & $\%$ \\
\hline
\end{tabular}




\begin{tabular}{|c|c|c|c|c|}
\hline \multirow{8}{*}{ 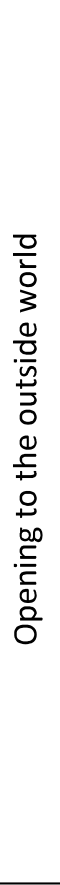 } & \multirow{2}{*}{ Trade openness } & Ratio of Total Imports to GRP & 0.1132 & $\%$ \\
\hline & & Ratio of Total Exports to GRP & 0.1334 & $\%$ \\
\hline & \multirow{2}{*}{$\begin{array}{l}\text { Investment } \\
\text { openness }\end{array}$} & $\begin{array}{l}\text { Total Investment of Foreign- } \\
\text { invested Enterprises }\end{array}$ & 0.1324 & $\begin{array}{l}\text { Million } \\
\text { dollar }\end{array}$ \\
\hline & & $\begin{array}{l}\text { Total Import and Export Goods } \\
\text { of Foreign-invested Enterprises }\end{array}$ & 0.1204 & $\begin{array}{l}\text { Ten } \\
\text { thousand } \\
\text { dollars }\end{array}$ \\
\hline & \multirow{2}{*}{$\begin{array}{l}\text { Production } \\
\text { openness }\end{array}$} & $\begin{array}{c}\text { Ratio of Sales Value of Foreign- } \\
\text { invested Industrial Enterprises } \\
\text { to GRP }\end{array}$ & 0.1192 & $\%$ \\
\hline & & $\begin{array}{c}\text { Proportion of Main Business } \\
\text { Income to Total Income of } \\
\text { Foreign-invested Industrial } \\
\text { Enterprises }\end{array}$ & 0.1207 & $\%$ \\
\hline & \multirow{2}{*}{$\begin{array}{l}\text { Technology } \\
\text { openness }\end{array}$} & $\begin{array}{c}\text { Transaction Value in Technical } \\
\text { Markets }\end{array}$ & 0.1407 & $\begin{array}{l}\text { Billion } \\
\text { Yuan }\end{array}$ \\
\hline & & $\begin{array}{c}\text { Proportion of Technology Import } \\
\text { Contracts in Total Technology } \\
\text { Market Transactions }\end{array}$ & 0.1200 & $\%$ \\
\hline \multirow{11}{*}{ 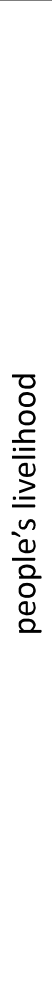 } & \multirow{3}{*}{$\begin{array}{l}\text { Employment } \\
\text { income }\end{array}$} & $\begin{array}{c}\text { Registered Urban } \\
\text { Unemployment Rate }\end{array}$ & 0.1058 & $\%$ \\
\hline & & $\begin{array}{c}\text { Per Capita Disposable Income of } \\
\text { Households }\end{array}$ & 0.1075 & Yuan \\
\hline & & $\begin{array}{l}\text { Per Capita Consumption } \\
\text { Expenditure of Households }\end{array}$ & 0.1042 & Yuan \\
\hline & \multirow{4}{*}{ Social security } & $\begin{array}{l}\text { Per Capita Investment in } \\
\text { Education }\end{array}$ & 0.1008 & Yuan \\
\hline & & $\begin{array}{l}\text { Average Student-Teacher Ratio } \\
\text { by Level of Regular Schools }\end{array}$ & 0.0761 & Null \\
\hline & & $\begin{array}{l}\text { Number of Beds Per } 10,000 \\
\text { People in Medical and Health } \\
\text { Institutions }\end{array}$ & 0.0722 & pcs \\
\hline & & Pension Insurance Coverage & 0.0774 & $\%$ \\
\hline & \multirow{4}{*}{ Public services } & $\begin{array}{c}\text { Number of Beds for the Aged } \\
\text { Per } 1000 \text { People }\end{array}$ & 0.0932 & pcs \\
\hline & & $\begin{array}{l}\text { Number of Public Library } \\
\text { Institutions }\end{array}$ & 0.0942 & pcs \\
\hline & & Green Coverage of Built-up Area & 0.0737 & $\%$ \\
\hline & & $\begin{array}{l}\text { Public Transport Vehicles Per } \\
\text { 10,000 People }\end{array}$ & 0.0949 & pcs \\
\hline
\end{tabular}




\section{Evaluation method}

The evaluation of high-quality development involves a lot of information, and the indexes only cover a part of the information, which is a typical problem of incomplete information. Grey system theory is a good method to deal with systems with incomplete information. Therefore, we use the improved G1 method based on grey correlation degree (Huang, Wang \& Cai , 2015) to calculate the weight of evaluation index. Coordination degree model based on bull's-eye distance (Huang, Wang \& Cai , 2015) is applied to measure coordination level among subsystems. Due to the limitation of space, improved G1 method based on grey correlation degree is omitted here.

\section{Coordination Degree Model based on Bull's-eye Distance}

Suppose that $i \in I=\{1,2, \cdots, l\}$ stands for provincial high-quality development system's subscript, and $l$ stands for number of province; $j \in J=\{1,2, \cdots, m\}$ stands for subsystem subscript, and $m$ stands for number of subsystem; $k \in K=\{1,2, \cdots, n\}$ stands for index subscript, and $n$ stands for number of index for each subsystem; $x_{i j k}$ stands for dimensionless value of index $k$ of subsystem $j$ for high-quality development system of province $i ; w_{j k}$ stands for weight of index $k$ of subsystem $j ; y_{i j}$ stands for development degree of subsystem $j$ for high-quality development system of province $i ; y_{i j}^{\prime}$ stands for ideal development degree of subsystem $j$ for high-quality development system of province $i ; c_{i}$ stands for coordination degree of high-quality development system of province $i$.

Then, development degree of subsystem $j$ for high-quality development system of province $i$ is expressed by

$$
y_{i j}=\sum_{k=1}^{n} w_{j k} x_{i j k}, k=1,2, \cdots, n, j=1,2, \cdots, m, i=1,2, \cdots, l
$$

The bull's-eye distance $r_{i}$ is used to measure the distance between system actual state and ideal coordination state for each subsystem of high-quality development system of province $i$. It can be expressed by

$$
r_{i}=\left[\left(y_{i 1}-y_{i 1}^{\prime}\right)^{2}+\left(y_{i 2}-y_{i 2}^{\prime}\right)^{2}+\cdots+\left(y_{i m}-y_{i m}^{\prime}\right)^{2}\right]^{1 / 2}, i=1,2, \cdots, l
$$


The greater bull's-eye distance is, the more deflected from actual state to ideal coordination state is, the lower system coordination degree is. In accordance with representative meaning of other coordination degree models' calculation result, coordination degree model based on bull's-eye distance is defined by formula (3).

$$
c_{i}=\left(\sqrt{1-r_{i} /\left\lceil\max _{1 \leq i \leq l} r_{i}\right\rceil}\right)^{\varphi}, i=1,2, \cdots, l
$$

where $\varphi(\varphi>0)$ is adjustment coefficient, $\left[\max _{1 \leq i \leq l} r_{i}\right\rceil$ is the smallest integer greater than or equal to $\max _{1 \leq i \leq l} r_{i}$.

$c_{i}$ is between 0 and 1 . The greater its value is, the more coordinated the highquality development system is.

Coordination is in the consistency state among the subsystems. Ideal coordination state should be a state of consistent development for each subsystem. Therefore, the median of subsystem's development degree is set as the value of an ideal coordination state. Ideal value of development degree, formula (1), and formula (2) are generated into formula (3), and let $\varphi=2$, coordination degree model of China's high-quality development system is got.

Comprehensive Development Degree and Coordinated Development Degree

Comprehensive development degree $y_{i}$ is calculated by the linear weight synthesis model. Suppose that each subsystem is equally important, their weights are equal. The algorithm is expressed by formula (4).

$$
y_{i}=\frac{1}{m} \sum_{j=1}^{m} y_{i j}, i=1,2, \cdots, l
$$

Coordinated development degree $d_{i}$ is calculated by the nonlinear weight synthesis model. Usually, Weights of comprehensive development degree and coordination degree are also equal. The algorithm is expressed by formula (5).

$$
d_{i}=\sqrt{y_{i} c_{i}}, i=1,2, \cdots, l
$$

\section{Evaluation Results and Analysis}

\section{Data Sources}

High-quality development system of 30 provinces, municipalities and autonomous regions in China are taken as the evaluation objects. Tibet isn't included because some data can't be collected. The data are collected from China Statistical Yearbook 2017, China Science and Technology Statistical Yearbook 
2017, and China High-tech Industry Statistical Yearbook 2017. The improved G1 method based on grey correlation degree is applied to calculate the weight of indexes that is shown by Table 1 .

\section{Comprehensive Development Degree}

The comprehensive development degree of high-quality development system is distributed in the interval [0.3290, 0.6653]. That of Beijing is the biggest, but its value is only 0.6653 . Only 6 provinces' comprehensive development degrees including Beijing, Shanghai, Guangdong, Jiangsu, Tianjin and Zhejiang are greater than 0.5 (Table 2). The national average is 0.4236 . Overall, the comprehensive development degree is relatively low.

From the perspective of geographical distribution, the top eight provinces are all in the eastern region. Chongqing and Hubei respectively rank 9th and 10th. Among provinces ranked in the middle 10, Sichuan, Inner Mongolia, Guangxi, Shaanxi are located in the western region, Anhui, Hunan, and Henan in central region, Liaoning and Jilin in northeast region, and Hainan in eastern region. Most of the last 10 provinces are located in the western region, Jiangxi and Shanxi in central region, Heilongiiang in northeast region, and Hebei in eastern region (Table 2). The average of comprehensive development degree in the eastern region, northeast region, central region and western region is $0.5235,0.3757,0.3825$ and 0.3691 respectively. The average of eastern region is significantly larger than that of other regions. There is an obviously geographical distribution characteristic of east high and west low.

Table 2: Comprehensive development degree

\begin{tabular}{|c|c|c|c|c|c|}
\hline province & $\begin{array}{c}\text { comprehensive } \\
\text { development } \\
\text { degree }\end{array}$ & province & $\begin{array}{c}\text { comprehensive } \\
\text { development } \\
\text { degree }\end{array}$ & province & $\begin{array}{c}\text { comprehensive } \\
\text { development } \\
\text { degree }\end{array}$ \\
\hline Beijing & 0.6653 & Hainan & 0.3997 & Hebei & 0.3714 \\
\hline Shanghai & 0.6571 & Anhui & 0.3980 & Jiangxi & 0.3702 \\
\hline Guangdong & 0.5716 & Liaoning & 0.3956 & Guizhou & 0.3614 \\
\hline Jiangsu & 0.5534 & Sichuan & 0.3939 & Ningxia & 0.3580 \\
\hline Tianjin & 0.5395 & Hunan & 0.3910 & Gansu & 0.3540 \\
\hline Zhejiang & 0.5349 & $\begin{array}{c}\text { Inner } \\
\text { Mongolia }\end{array}$ & 0.3857 & $\begin{array}{c}\text { Heilong } \\
\text { jiang }\end{array}$ & 0.3522 \\
\hline Fujian & 0.4876 & Guangxi & 0.3797 & Qinghai & 0.3444 \\
\hline Shandong & 0.4541 & Jilin & 0.3792 & Shanxi & 0.3439 \\
\hline Chongqing & 0.4473 & Henan & 0.3766 & Yunnan & 0.3307 \\
\hline Hubei & 0.4150 & Shaanxi & 0.3763 & Xinjiang & 0.3290 \\
\hline
\end{tabular}


Table 3: Average of subsystem's development degree in China's four regions

\begin{tabular}{|c|c|c|c|c|c|c|}
\hline $\begin{array}{c}\text { Region } \\
\text { Subsystem }\end{array}$ & $\begin{array}{c}\text { Eastern } \\
\text { region }\end{array}$ & $\begin{array}{c}\text { Northeast } \\
\text { region }\end{array}$ & $\begin{array}{c}\text { Central } \\
\text { region }\end{array}$ & $\begin{array}{c}\text { Western } \\
\text { region }\end{array}$ & Nationwide & variance \\
\hline $\begin{array}{c}\text { innovation } \\
\text { development }\end{array}$ & 0.5915 & 0.4081 & 0.4694 & 0.4212 & 0.4726 & 0.1115 \\
\hline $\begin{array}{c}\text { urban-rural } \\
\text { coordination }\end{array}$ & 0.5810 & 0.4793 & 0.4886 & 0.4670 & 0.5040 & 0.0721 \\
\hline $\begin{array}{c}\text { ecological } \\
\text { environment }\end{array}$ & 0.4195 & 0.3250 & 0.3140 & 0.3068 & 0.3413 & 0.0818 \\
\hline $\begin{array}{c}\text { opening to the } \\
\text { outside world }\end{array}$ & 0.3834 & 0.1245 & 0.0899 & 0.0962 & 0.1735 & 0.1824 \\
\hline people's livelihood & 0.6419 & 0.5415 & 0.5505 & 0.5545 & 0.5721 & 0.0737 \\
\hline
\end{tabular}

Eastern region

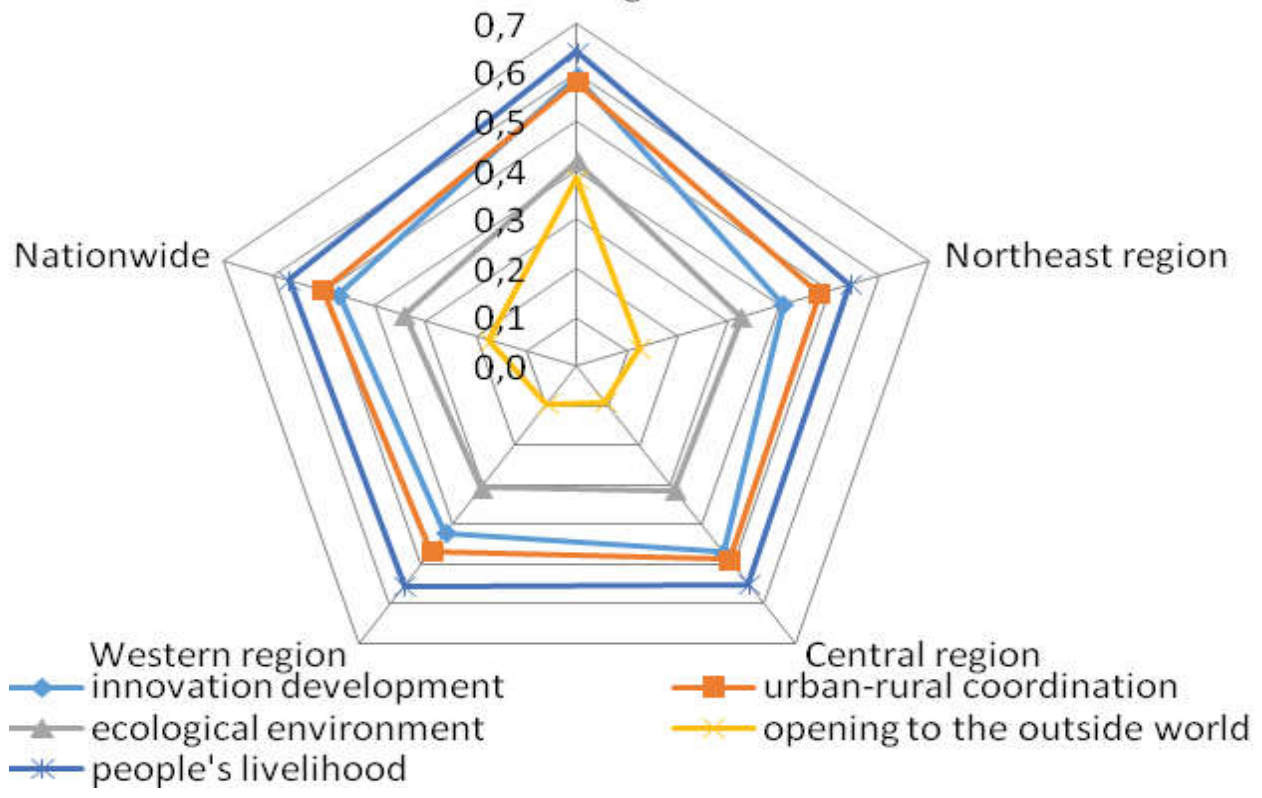

Figure 1: Average of subsystem's development degree

The average of five subsystems' development degree in the four regions of China is shown in Table 3 and Figure 1. The average of opening to the outside world subsystem's development degree is smallest, and this subsystem is with the most imbalanced development. There is a relatively high level of opening in eastern provinces such as Shanghai, Guangdong, Jiangsu, Beijing, Fujian, Tianjin, and Zhejiang. The level of opening in the central and western regions is generally low, especially in provinces such as Qinghai, Xinjiang, Yunnan, Ningxia, Inner Mongolia, and Shanxi. The development degree of opening subsystem of Shanghai is 21.6 times than that of Qinghai. Innovation development among China's four regions is also imbalanced, and the average of innovation development subsystem's 
development degree in eastern region is 1.45 times than that in northeast region. The average of ecological environment subsystem's development degree is obviously smaller than that of innovation development, urban-rural coordination, and people's livelihood subsystem. Ecological environment subsystem is also the weak point of China's high-quality development system.

\section{Coordination Degree}

The coordination degree of high-quality development system is distributed in the interval $[0.5262,0.8672]$. According to the OECD's criteria, the coordination states are defined as excellent coordination, good coordination, moderate coordination, mild coordination, low imbalance, moderate imbalance and serious imbalance, whose coordination degrees are respectively $(0.9,1],(0.8,0.9],(0.7,0.8],(0.6,0.7]$, $(0.5,0.6],(0.4,0.5]$, and $[0,0.4]$. There is no province with excellent coordination. Shanghai comes to the state of good coordination, 6 provinces such as Hainan, Fujian, Beijing, Guangdong, Jiangsu and Liaoning are in the state of moderate coordination, 14 provinces such as Gansu, Tianjin, Guizhou, Chongqing etc. are in the state of mild coordination, and 9 provinces such as Qinghai, Henan, Hubei, Xinjiang, Anhui, Shaanxi, Hunan, Hebei and Inner Mongolia are in the state of low imbalance (Table 4).

From the perspective of geographical distribution, the coordination degree of some provinces in central and western regions is bigger than that of some provinces in eastern regions. For example, the coordination degrees of Gansu and Guizhou respectively rank 8 th and $10^{\text {th }}$ (Table 4).The average of coordination degree in eastern, northeast, central and western regions are $0.7063,0.6550$, 0.5918 and 0.6122 respectively. Therefore, the spatial distribution characteristics of coordination degree are east high and central low.

Table 4: Coordination Degree

\begin{tabular}{|c|c|c|c|c|c|}
\hline province & $\begin{array}{c}\text { coordination } \\
\text { degree }\end{array}$ & province & $\begin{array}{c}\text { coordination } \\
\text { degree }\end{array}$ & province & $\begin{array}{c}\text { coordination } \\
\text { degree }\end{array}$ \\
\hline Shanghai & 0.8672 & Chongqing & 0.6457 & Sichuan & 0.6034 \\
\hline Hainan & 0.7776 & Heilongjiang & 0.6326 & Qinghai & 0.5987 \\
\hline Fujian & 0.7678 & Yunnan & 0.6291 & Henan & 0.5965 \\
\hline Beijing & 0.7463 & Guangxi & 0.6230 & Hubei & 0.5950 \\
\hline Guangdong & 0.7219 & Jilin & 0.6215 & Xinjiang & 0.5908 \\
\hline Jiangsu & 0.7179 & Shandong & 0.6163 & Anhui & 0.5699 \\
\hline Liaoning & 0.7108 & Zhejiang & 0.6128 & Shaanxi & 0.5699 \\
\hline Gansu & 0.6873 & Shanxi & 0.6115 & Hunan & 0.5668 \\
\hline Tianjin & 0.6731 & Jiangxi & 0.6112 & Hebei & 0.5621 \\
\hline Guizhou & 0.6564 & Ningxia & 0.6036 & $\begin{array}{c}\text { Inner } \\
\text { Mongolia }\end{array}$ & 0.5262 \\
\hline
\end{tabular}




\section{High-quality Development Degree}

Coordinated development degree is applied to measure the high-quality development degree of 30 provinces in China. The high-quality development degrees are shown in Table 5. The provinces with high-quality development degree greater than 0.5 are mainly distributed in the eastern region, except for Chongqing and Liaoning. The provinces with high-quality development degree between 0.47 and 0.5 are distributed in various regions. Hubei, Anhui, Jiangxi, Henan, Hunan are located in the central region, Gansu, Sichuan, Guizhou, Guangxi are located in the western region, Jilin, Heilongjiang are located in the northeast region. The provinces with high-quality development degree below 0.47 are mainly in the western region, except for Shanxi and Hebei (Table 5).The averages of highquality development degree in eastern, northeast, central and western region are $0.6063,0.4951,0.4754$ and 0.4747 respectively. It can be seen that high-quality development degree has obviously regional distribution characteristics of east high and west low.

Table 5: High-quality development degree

\begin{tabular}{|l|l|l|l|l|l|}
\hline \multicolumn{1}{|c|}{ province } & $\begin{array}{c}\text { High-quality } \\
\text { Development } \\
\text { Degree }\end{array}$ & province & $\begin{array}{c}\text { High-quality } \\
\text { Development } \\
\text { Degree }\end{array}$ & province & $\begin{array}{c}\text { High-quality } \\
\text { Development } \\
\text { Degree }\end{array}$ \\
\hline Shanghai & 0.7549 & Shandong & 0.5290 & $\begin{array}{l}\text { Heilong } \\
\text { jiang }\end{array}$ & 0.4720 \\
\hline Beijing & 0.7047 & Hubei & 0.4969 & Hunan & 0.4708 \\
\hline Guangdong & 0.6424 & Gansu & 0.4933 & Ningxia & 0.4649 \\
\hline Jiangsu & 0.6303 & Sichuan & 0.4875 & Shaanxi & 0.4631 \\
\hline Fujian & 0.6119 & Guizhou & 0.4870 & Shanxi & 0.4586 \\
\hline Tianjin & 0.6026 & Guangxi & 0.4863 & Hebei & 0.4569 \\
\hline Zhejiang & 0.5725 & Jilin & 0.4855 & Yunnan & 0.4561 \\
\hline Hainan & 0.5575 & Anhui & 0.4763 & Qinghai & 0.4541 \\
\hline Chongqing & 0.5375 & Jiangxi & 0.4757 & $\begin{array}{l}\text { Inner } \\
\text { Mongolia }\end{array}$ & 0.4505 \\
\hline Liaoning & 0.5303 & Henan & 0.4740 & Xinjiang & 0.4409 \\
\hline
\end{tabular}

In order to further analyze the high-quality development of various provinces in China, we divide the comprehensive development degree into the interval $(0.4,0.7]$, $(0.37,0.4]$ and $[0.32,0.37]$, whose development states are well development, medium development and low development respectively. We classify the provinces based on comprehensive development degree and coordination degree. Classification result is shown in Figure 2. 


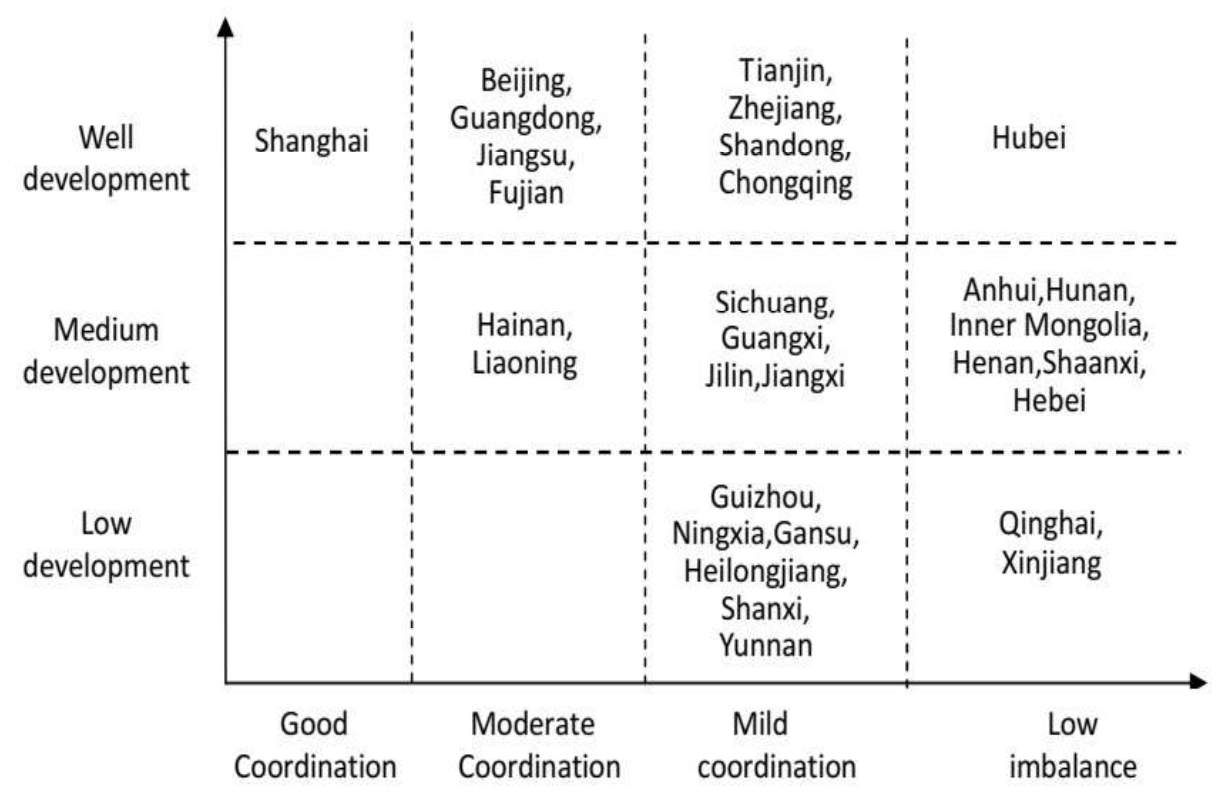

Figure 2: Classification results with comprehensive development degree and coordination degree

Shanghai ranks at the first in terms of high-quality development degree, who comes to a state of well development and good coordination. Compared with other subsystems, the development of Shanghai's ecological environment subsystem is relatively weak. If Shanghai can further improve its ecological environment, it is expected to be at a state of higher development level with excellent coordination. There are mismatching between comprehensive development degree and coordination degree for some provinces, that is, high development level and low coordination level, or low development level and high coordination level. The high development level and low coordination level is that high development degree of some subsystems result in the high comprehensive development degree, but the coordination degree is low. For example, the development degree of Hubei's five subsystems are $0.4909,0.5378,0.3276,0.1352,0.5837$ respectively, with the result that its comprehensive development degree ranks 10th, but its coordination degree only ranks 24 th. The low development level and high coordination level is that the coordination degree is relatively high, but the comprehensive development degree is low. For example, Gansu ranks 8th in coordination degree, but it ranks 25th in comprehensive development degree, Guizhou ranks 10th in coordination degree, but it ranks 23rd in comprehensive development degree. 


\section{Conclusion}

Based on the new development concept of innovative, coordination, green, open and share,we put forward that the high-quality development system is an organic whole composed of five subsystems, including innovation development, urban-rural coordination, ecological environment, opening to the outside world, and people's livelihood. The high-quality development is considered as the full and coordination development of five subsystems. On the basis of that, the evaluation index system is established to reflect the development quality of five subsystems. Based on improved G1 method based on grey correlation degree and coordination degree model based on bull's-eye distance, we analyze the highquality development level of 30 provinces in China in 2016, and obtain relevant conclusions and inspirations to promote China's high-quality development.

Firstly, the evaluation results show that comprehensive development degree and coordination degree have obviously geographical distribution characteristic, respectively presenting a spatial feature of east high and west low, and east high and central low. The imbalance of high-quality development is prominent, showing obviously spatial pattern of east high and west low. A portion of provinces are at high development level but low coordination level, and parts of provinces are at low development level but high coordination level. It is necessary to focus on the development of weak subsystems in each province, and improve the development degree of central and western regions. Secondly, the results show that the opening subsystem is the smallest in the mean of comprehensive development degree, and also is the most imbalanced one. The opening level of eastern provinces is higher than that of central and western provinces. It is imperative to form an open pattern of east-west and east-central interaction, and accelerate the formation of a new pattern of comprehensive opening up. Thirdly, the results show that ecological environment is another weakness of China's high-quality development. It is necessary to strengthen environmental governance, fight against pollution, and reduce the total amount of pollutant emissions. Fourthly, the results show that innovation development among China's four regions is also imbalanced. Innovation development degree of northeast region and western region is relatively low. The two regions should deeply implement the innovation driven development strategy, and make innovation as a powerful driving force for high-quality development.

\section{Acknowledgements}

This work was supported by the National Natural Science Foundation of China (Grant No. 71602035 and Grant No. 71403052), the National Social Science Foundation of China (Grant No.19BGL031). 


\section{References}

An, S.X. (2018). A Research on the Path of Promoting High-quality Economic Development: A Literature Review. Contemporary Economic Management, 40(9), 11-17. DOI: 10.13253/ j.cnki.ddjjgl.2018.09.002

Chen, S.Y., \& Chen, D.K. (2018).Air Pollution, Government Regulations and High-quality Economic

Development. Economic Research Journal, 2, 20-34.

Huang, M., \& Ren, D. (2019). Constructing and Calculating of People-Centered HighQuality Development Index System. Statistics \& Information Forum, 34(10), 36-42.

Huang, X.H., Wang, W.P. \& Cai B.Q. (2015). Evaluation Method for System Coordination Development Based on Grey System Theory. The Journal of Grey System, 27(1), 80-93.

Jin, B .(2018). Study on the "High-Quality Development" Economics. China Industrial Economics, 4, 5-18. DOI: 10.19581/j.cnki.ciejournal.2018.04.001

Li, T.X., Li, Y., An, D.F. et al. (2019). Mining of the Association Rules between Industrialization Level and Air Quality to Inform High-quality Development in China. Journal of Environmental Management, 246, 564-574. DOI: 10.1016/j. jenvman.2019.06.022

Li, Y.X. \& Zeng, C. (2019). Government Size, Technology Innovation and High-Quality Development: A Study Based on the Mediating Effect of Entrepreneurship. Fudan Journal (Social Sciences), 3,155-166. DOI: 10.3969/j.issn.0257-0289.2019.03.016

Liu, S.M., Zhang, S.J. \& Zhu H.D .(2019). Study on the Measurement and High-Quality Economy Development Effect of National Innovation Driving Force. The Journal of Quantitative \& Technical Economics, 4, 3-23. DOI:10.13653/j.cnki.jqte.2019.04.001

Ren, B.P., \& Li Y.M.(2018) . Study on the Construction of Chinese High-quality Development Evaluation System and the Path of Its Transformation in the New Era. Journal of Shaanxi Normal University (Philosophy and Social Sciences Edition), 47(3), 105-113. DOI: 10.15983/j.cnki.sxss.2018.0421

Ren, B.P., \& Wen, F.A. (2018). The Criteria, Determinants and Ways to Achieve High Quality Development in China in the New Era. Reform, 4, 5-16.

Ruan, J. \& Liu, Y.N. (2019). Measurement of Development Achievements and Driver Analysis from the Perspective of Sharing Concept. Statistics \& Information Forum, 34(7), 35-43. DOI: 10.3969/ j.issn. 1007-3116.2019.07.005

Shi, D. \& Li, P. (2019). Measurement and International Comparison of High Quality Economic Development in China. Southeast Academic Research, 5,169-180. DOI: 10.13658/j.cnki.sar. 2019.05.019

Tian,S.H., Li, X.Y. \& Wang, X. (2019). Bi-directional FDI and the High-Quality Economic Development in China. Shanghai Journal of Economics, 8, 25-36. DOI: 10.19626/ j.cnki.cn31-1163 /f.2019.08.005

Wang, H.Y., Li, X.Y. \& Xu, Y.L. (2019). Research on Performance Evaluation and Influencing Factors of High-quality Economic Development Driven by Scientific and Technological Innovation in China. Economist, 11, 64-74. DOI: 10.16158/j. cnki.51-1312/f.2019.11.008

Wang, W. (2017). The Evaluation of Coordinated Development Level between Urban and Rural and Its Spatial-Temporal Pattern in Yangtze River Economic Zone. Economic Geography, 37(8), 60-66. DOI: 10.15957/j.cnki.jjdl.2017.08.008 
Wei, M. \& Li, S.H.(2018).Study on the Measurement of Economic High-Quality Development Level in China in the New Era. The Journal of Quantitative \& Technical Economics, 11, 3-20. DOI: 10.13653/j.cnki.jqte.2018.11.001

Xu, X.C., Zheng, Z.X. \& Zhang, Z.W. (2019). Study on the Balanced Development Status and Countermeasures in China: based on a comprehensive analysis of balanced development index of Tsinghua University. Management World, 5, 15-28. DOI: 10.19744/j.cnki.11-1235/ f.2019.0063

Yang, C.J., Yang, W.K. \& Li, N. (2018). Study on Difference Decomposition and Spatial Convergence of Regional Openness in China. R\&D Management, 30(1), 115-125. DOI: $10.13581 /$ j.cnki.rdm.20180103.005

Yang, R.F. \& Li, N.N. (2019). Industrial Structure Change and China's Economic Growth. Economist, 8, 27-38. DOI:10.16158/j.cnki.51-1312/f.2019.08.003

Yuan, X.L., Di,Q., \& Li, Z.D. (2018). Analysis and Enlightenment between China's Economic Development and Environmental Quality in 40 Years of Reform and Opening-Up. Journal of Xi'an Jiaotong University (Social Sciences), 38(6), 113118. DOI: $10.15896 /$ j.xjtuskxb.201806013 